First publ. in: GLIA 23 (1998), pp. 257-270

\title{
E 587 Antigen Is Upregulated by Goldfish Oligodendrocytes After Optic Nerve Lesion and Supports Retinal Axon Regeneration
}

\author{
RICHARD ANKERHOLD, CHRISTIAN A. LEPPERT, MARTIN BASTMEYER, \\ AND CLAUDIA A.O. STUERMER* \\ Division of Biology, University of Konstanz, Konstanz, Germany
}

KEY WORDS L1; axon regeneration; glial cells; fish; visual system; optic nerve; functional assay; immunoel ectronmicroscopy; astrocytes

\begin{abstract}
The properties of glial cells in lesioned nerves contribute quite substantially to success or failure of axon regeneration in the CNS. Goldfish retinal axons regenerate after optic nerve lesion (ONS) and express the L 1-like cell adhesion protein E587 antigen on their surfaces. Goldfish oligodendrocytes in vitro also produce E587 antigen and promote growth of both fish and rat retinal axons. To determine whether glial cells in vivo synthesize E587 antigen, in situ hybridizations with E587 antisense CRNA probes and light- and electron microscopic E587 immunostainings were carried out. After lesion, the goldfish optic nerve/tract contained glial cells expressing E587 mRNA, which were few in number at 6 days after ONS, increased over the foll owing week and declined in number thereafter. Also, E587-immunopositive elongated cells with ultrastructural characteristics of oligodendrocytes were found. Thus, glial cells synthesize E587 antigen in spatiotemporal correlation with retinal axon regeneration. To determine the functional contribution of E587 antigen, axon-oligodendrocyte interactions were monitored in co-cul ture assays in the presence of $\mathrm{F} \mathrm{ab}$ fragments of a polyclonal E587 antiserum. E587 Fabs in axon-glia co-cultures prevented the normal tight adhesion of goldfish retinal growth cones to oligodendrocytes and blocked the preferential growth of fish and rat retinal axons on the oligodendrocyte surfaces.

The ability of glia in the gol dfish visual pathway to upregulate the expression of E587 antigen and the growth supportive effect of oligodendrocyte-associated E587 antigen in vitro suggests that this L1-like adhesion protein promotes retinal axon regeneration in the goldfish CNS.
\end{abstract}

\section{INTRODUCTION}

In the central nervous system (CNS) of warmblooded vertebrates, axons fail to regenerate after lesion (reviewed in Schwab et al., 1993). In coldblooded vertebrates such as fish, axotomized neurons of the CNS re-extend axons and restore functionally appropriate connections with their targets (reviewed in Gaze, 1970).

Success and failure of axon regeneration apparently depends on the glial cell environment as well as on intrinsic properties of the neurons (Fawcett, 1992; Stuermer et al., 1992). The nonpermissive substrate properties of reactive astrocytes and oligodendrocytes are responsible for the failure of axon regeneration in the avian and mammalian CNS (reviewed in Reier and Houlé, 1988; Schwab et al., 1993; Bähr and Bonhoeffer, 1994). Schwann cells in the peripheral nervous system (PNS) support the regrowth of cut axons (reviewed in Fawcett and Keynes, 1990; Fu and Gordon, 1997).

\footnotetext{
Contract grant sponsor: DF G; Contract grant number: SFB 156.

R.A. and C.A.L. contributed equally to this study.

*Correspondence to: Claudia A.O. Stuermer, Division of Biology, University of Konstanz, D-78434 Konstanz, Germany.

E-mail: claudia.stuermer@uni-konstanz.de

Received 7 September 1997; Accepted 29 October 1997
} 
Much as in mammals, the major glia cell types in fish CNS are oligodendrocytes and astrocytes (Wolburg, 1981; Waehneldt, 1990; Maggs and Scholes, 1990; Bastmeyer et al., 1993) and Schwann cells in the PNS (Scherer and Easter, 1984). The response of fish CNS glial cells to fiber tract injury has been most intensively studied in the visual pathway. When the optic nerve of the fish is cut, the nonpermissive glial scars which negatively affect the regrowth of lesioned CNS axons in mammals do not form (Hirsch et al., 1995). Moreover, CNS myelin and oligodendrocytes do not produce neurite growth inhibitors (Bastmeyer et al., 1991; Wanner et al., 1995) which are known to block axon regrowth in the CNS of mammals (Bandtlow et al., 1990; 1993). Instead, oligodendrocytes in the fish optic nerve/tract respond to fiber tract lesion much like PNS Schwann cells (Bunge and Hopkins, 1990) in that they change from myelinating to apparently axon growth promoting glial cells which ultimately remyelinate the regenerated axons (Wol burg, 1981; Stuermer and Easter, 1984).

When isolated from normal or lesioned optic nerves, goldfish oligodendrocytes in culture acquire an elongated shape, proliferate and synthesize the cell adhesion molecules E587 antigen and NCAM (Bastmeyer et al., 1994). Axons from goldfish retinal explants grow extremely well on such oligodendrocytes (Bastmeyer et al., 1993). Moreover, an impressive increase in axon outgrowth was observed in a cross species co-culture assay when retinal explants of adult rats were offered a substrate consisting of gol dfish oligodendrocytes (Bastmeyer et al., 1993).

Glial cells in the injured zebrafish optic nerve were found to synthesize mRNAs of NCAM, LI.1 and L1.2 (Bernhardt et al., 1996). L 1.1 and L 1.2 are the zebrafish homol ogues of the cell adhesion molecule L 1 (Tongiorgi et al., 1995). Their synthesis supports the contention that fish glial cells upregulate the production of cell adhesion molecules following CNS fiber tract injury.

Sequence comparison did not indicate whether E587 antigen is the goldfish homolog of any of the previously identified molecules or if it is an additional member of the L1 family (Giordano et al., 1997; Hortsch, 1996). However, E587 antigen function is that of L1-like adhesion proteins. E587 antigen was shown to mediate axon fasciculation, enhance growth cone advance and promote retinal ganglion cell (RGC) axon growth when offered to axons as substrate (Bastmeyer et al., 1995). When the goldfish optic nerve is severed, all retinal ganglion cells re-express E587 mRNA. The regenerating goldfish retinal axons carry E 587 antigen over their entire surface (Vielmetter et al., 1991; Giordano et al., 1997). It is likely, therefore, that E587 antigen on goldfish ol igodendrocytes participates in the increase in RGC axon growth along these glial cells in vitro (Bastmeyer et al., 1993).

If this interaction is relevant during RGC axon regeneration in vivo, one would expect expression of E587 antigen by goldfish glial cells in vivo. To determine whether the L 1-like cell adhesion molecule E587 antigen is directly involved in these interactions, we applied Fab fragments (E587 Fabs) of a polyclonal antiserum against E587 antigen to axon-glia cocultures. The E587 Fabs were shown to interfere with E587 antigen function in earlier studies (Bastmeyer et al., 1995; Weiland et al., 1997). Furthermore, to determine whether E587 antigen (mRNA and protein) is upregulated by optic nerve glia, particularly oligodendrocytes, in response to optic nerve lesion, in situ hybridization techniques with E587 CRNA probes and E587 immunostaining experiments were carried out with intact goldfish optic nerve/tracts, and after optic nervelesion.

\section{MATERIALS AND METHODS}

Goldfish were raised in our breeding colony at the University of Konstanz at $20^{\circ} \mathrm{C}$. Optic nerve transection (as described in Vielmetter and Stuermer, 1989) and aspiration of the retina were performed in 6 to $8 \mathrm{~cm}$ long fish under MS 222 (3-aminobenzoic acid ethyl ester, Sigma) anesthesia in compliance with animal welfare legislation. The retina was removed by making a small dorsal incision in the eye. The tip of a pipette connected to a suction device was inserted, and the retina aspirated away.

\section{I mmunohistochemistry on Cryostat Sections}

At various times after optic nerve section (ONS) or after removal of the retina, the optic nerve/tract and tectum opticum was dissected out, attached by suction to a nylon filter, embedded in Tissue Tek (Miles) and frozen in liquid nitrogen. Longitudinal cryosections of 10-12 $\mu \mathrm{m}$ were collected on coated slides (SuperF rost, Menzel-Gläser), air-dried, dehydrated for $5 \mathrm{~min}$ in methanol $\left(-20^{\circ} \mathrm{C}\right)$, and rinsed in phosphate-buffered saline (PBS, pH 7.4). Sections were incubated overnight at $4^{\circ} \mathrm{C}$ with either of the two monoclonal antibodies (mAb) against the E587 antigen: mAb E587 (IgG) (Vielmetter et al., 1991) or mAb E 17 (I gG) (Weiland et al., 1997). For simplicity, we use "E587-positive" for E587 or E17 immunostained cells. After washes in PBS ( $3 \times 5 \mathrm{~min}$ ), a mixture of rhodamine (TRITC)-conjugated I gG specific goat anti-mouse secondary antibody and fluoresceine (FITC)-conjugated IgM-specific donkey anti-mouse secondary antibody (both Dianova) was applied to the sections for 2-4 $\mathrm{h}$. The sections were rinsed, incubated in DAPI $(0.5 \mu \mathrm{g} / \mathrm{ml})$ for $10 \mathrm{~min}$ to visualize cell nuclei and mounted in a mixture of Mowiol (Hoechst), PBS and glycerol with n-propylgallate as anti-fading agent.

\section{I mmunoelectron Microscopy}

Indirect immunoel ectron microscopy was carried out according to Martini and Schachner (1986) with some modifications. Intact or regenerating optic nerve/tracts 
from goldfish were attached to nylon filters (Hybond $\mathrm{N}^{+}$, Amersham) and fixed overnight at $4{ }^{\circ} \mathrm{C}$ in $3 \%$ paraformaldehyde (PFA) and $0.1 \%$ glutaraldehyde in PBS. Vibratome sections $(50-70 \mu \mathrm{m})$ were treated with $0.3 \%$ hydrogen peroxide for $30 \mathrm{~min}$, washed in PBS $(3 \times 10 \mathrm{~min})$, and incubated overnight at $4^{\circ} \mathrm{C}$ in PBS containing $1 \%$ bovine albumin serum (BSA). Sections were then treated sequentially with $0.1 \mathrm{M} \mathrm{NaIO}_{4}$ (10 min), $1 \% \mathrm{NaBH}_{4}(15 \mathrm{~min}$ ), and $10 \%$ dimethyl sulfoxide (DMSO) in PBS (10 min). After washes in PBS containing 0.1\% DMSO (PBSD), mAb E $17(25 \mu \mathrm{g} / \mathrm{ml})$ was applied overnight at $4^{\circ} \mathrm{C}$. Control sections were immersed in PBS containing 1\% BSA instead of mAb E 17. Following washes in PBSD $(3 \times 30 \mathrm{~min})$ biotinylated anti-mouse IgG (Vector Laboratories) was applied overnight at $4^{\circ} \mathrm{C}$. The sections were washed again and then incubated in HRP-conjugated avidin (Vector Laboratories) for $2 \mathrm{~h}$, washed and postfixed in $0.5 \%$ glutaraldehyde (in PBS) overnight at $4^{\circ} \mathrm{C}$ and washed again. Sections were then immersed in diaminobenzidine hydrochloride (DAB) for $30 \mathrm{~min}$ and subjected to the staining procedure recommended by the manufacturer (Vector Laboratories). After postfixation in $2 \% \mathrm{OsO}_{4}$ (in PBS) for $30 \mathrm{~min}$, sections were embedded in Spurr's epoxy resin. Ultrathin sections were cut on a Reichert Ultrami crotome, and examined and photographed with a Zeiss EM 900 electron microscope.

\section{Nucleic Acid Probes and In Situ Hybridization}

E587 antigen cRNA probes were synthesized using standard protocols as described (Giordano et al., 1997). A pCRII vector containing a $1.2 \mathrm{~kb}$ insert coding for E587 antigen CRNA was linearized with Xhol or HindIII for production of antisense and sense probes, respectively. The cRNAs were labeled with digoxigenin (DIG) following the manufacturer's instructions (Boehringer Mannheim) and hydrolyzed to a mean size of 250 bases by a limited alkal ine hydrolysis (Wilkinson, 1992). The DIG-labeled cRNA probe was used to detect E587 antigen mRNA on longitudinal vibratom sections $(80 \mu \mathrm{m})$ of the goldfish optic nerve/tract at various times after ONS essentially following the protocol of Westerfield (1994). Intact or regenerating optic nerve/tracts from goldfish were attached to nylon filters $\left(\mathrm{Hybond} \mathrm{N}^{+}\right.$, Amersham) and fixed overnight at $4^{\circ} \mathrm{C}$ in $4 \%$ PFA in PBS. Vibratome sections were washed in PBS $(2 \times 10$ min) containing $0.1 \%$ Tween 20 (Sigma, PBST) and delipidated through a graded series of methanol. After washes in PBST $(2 \times 10 \mathrm{~min})$ the sections were exposed to proteinase $K(10 \mu \mathrm{g} / \mathrm{ml}$, Boehringer Mannheim) for $30 \mathrm{~min}$ at room temperature, rinsed in PBST, and postfixed in 4\% PFA for $20 \mathrm{~min}$ and washed again in PBST $(5 \times 15 \mathrm{~min})$. Prehybridization was performed for $1-2 \mathrm{~h}$ at $37^{\circ} \mathrm{C}$ followed by overnight incubation at $55^{\circ} \mathrm{C}$ in hybridization buffer (Westerfield, 1994) containing 100-200 ng/ml cRNA probe. The sections were washed at $55^{\circ} \mathrm{C}$ sequentially in $50 \%$ formamide/ $2 \times$ SSC $(2 \times 30 \mathrm{~min}), 2 \times \mathrm{SSC}(15 \mathrm{~min})$, and $0.2 \times \mathrm{SSC}$
( $2 \times 30 \mathrm{~min})$. Hybridized cRNA probes were visualized using alkaline phosphatase-conjugated anti-DIG Fab fragments and the BM Purple/Substrate (both Boehringer Mannheim). Only the antisense probe resulted in staining. Sections treated with the sense probe were blank.

\section{Polyclonal Antibodies}

Polyclonal antibodies were produced by injecting rabbits subcutaneously with immunopurified E587 antigen (Bastmeyer et al., 1995) and neurolin (Laessing et al., 1994), respectively. Complete Freund's adjuvant was used for the first injection and incompl ete for three subsequent injections at 3 week intervals. Fab fragments were obtained from the IgG fraction by using a Papain digestion kit (PIERCE). The specificity of Fab fragments against E587 antigen (abbr. E587 Fabs) and neurolin (neurolin Fabs) was verified on western blots with proteins from cell surface membranes of adult goldfish brains (Vielmetter et al., 1991; Weiland et al., 1997) and on cryosections of goldfish brains. Fab fragments of sera from untreated rabbits (non-immune Fabs) served as controls.

\section{Goldfish Glial Cell Cultures}

The isolation of goldfish glial cells and culture conditions were as described by Bastmeyer et al. (1993, 1994). In brief, small pieces from regenerating optic nerves and tracts from adult goldfish ( 2 weeks after optic nerve section) were incubated at $28^{\circ} \mathrm{C}$ for $20 \mathrm{~min}$ in L 15 with $0.3 \%$ collagenase (Worthington Seromed) and $0.1 \%$ dispase (Boehringer Mannhei $\mathrm{m}$ ). The enzyme mixture was replaced by L 15 with $20 \%$ FCS (fetal calf serum) and centrifuged at $200 \mathrm{~g}$ for $5 \mathrm{~min}$. The tissue was then resuspended in F12 medium (Ham's F 12 , Gibco), supplemented with $10 \%$ FCS and $0.4 \%$ methyl cellulose and plated onto polylysine/laminin-coated coverslips. These primary cultures were grown at $27^{\circ} \mathrm{C}$ to high density. They contain mainly oligodendrocytes which associate into a network-like carpet and astrocytes which form separate clusters (Bastmeyer et al., 1993, 1994). After 3-4 weeks, glial cells were removed from the coverslip with a rubber spatula, immersed in F12 culture medium, and re-explanted onto polylysine/ laminin-coated coversl ips. This procedure results in the gradual loss of astrocytes and after two to three changes, the cultures consist almost exclusively of oligodendrocytes.

\section{Goldfish Retinal Explants}

Goldfish retinal explants were prepared as previously described (Vielmetter and Stuermer, 1989). The retinae of adult gol dfish were isol ated 12-18 days after ONS and attached to nylon filters (Hybond, Amer- 
sham). Retina and filter were cut into stripes $300 \mu \mathrm{m}$ wide and placed ganglion cell layer down onto the coverslips carrying oligodendrocytes at low density. Small metal blocks were placed on the ends of the stripes to keep the retina in contact with the substrate. The cultures were kept in $\mathrm{F}-12$ medium at $22^{\circ} \mathrm{C}$.

\section{Videomicroscopy}

Contacts of goldfish retinal axons and goldfish oligodendrocytes in cultures treated with E587 Fabs (200 $\mu \mathrm{g} / \mathrm{ml})$, neurolin Fabs $(200 \mu \mathrm{g} / \mathrm{ml})$, or no Fabs (controls) were monitored with time-lapse videomicroscopy as described previously (Bastmeyer et al., 1991, 1995). Living axons were viewed with a $40 \times$ lens under phase contrast in an inverted microscope (Zeiss Axiovert) to which a camera was attached. The camera was connected to an image processor (Hamamatsu) and an S-VHS time-lapse recorder (Panasonic). A shutter which opened every $5 \mathrm{sec}$ for $200 \mathrm{msec}$ was inserted into the light path. Four images were averaged and recorded. These videorecordings were used to determine the duration of growth cone/ol igodendrocyte interaction in the presence of the added Fabs. In addition, growth cones contacting oligodendrocytes were viewed and photographed in 10-15 min intervals without recording them continuously.

\section{Rat Retinal Explants}

Theoptic nerves of adult rats were crushed intraorbitally under Kemint (Alvetra)/Rompun (Bayer) anaesthesia as described (Bähr et al., 1988; J ung et al., 1997). After 1 week, retinae were isolated in Hank's balanced salt solution (HBSS, Gibco) and attached to a filter (Millipore) as previously described (Bähr et al., 1988). For quantification of axon outgrowth, retinae were cut into eight pie-shaped pieces centered on the optic disc. Pieces were explanted, ganglion cell layer down, onto polylysine/laminin coated coverslips or onto carpets of goldfish ol igodendrocytes and grown in F12 medium at $28^{\circ} \mathrm{C}$ for 7 days (Bastmeyer et al., 1993). Small metal blocks were placed on the explants to keep the retina in contact with the substrate. For antibody perturbation experiments retinae attached to filters were cut into $400 \mu \mathrm{m}$ wide stripes with a tissue chopper. This method of dividing the retina resulted in roughly 20 explants instead of eight (see above) and was therefore more economical. However, as these stripes naturally contain fewer RGCs (2.5 times less) than the pie-shaped segments, they produced fewer regenerating axons. Furthermore, not all explants, either pie-shaped segments or stripes, extend axons (Bähr et al., 1988; Bastmeyer et al., 1993). Stripes were explanted onto goldfish oligodendrocytes and either grown in F12 medium al one, or in F 12 medium containing either E587 Fabs $(200 \mu \mathrm{g} / \mathrm{ml})$ or non-immune Fabs $(200 \mu \mathrm{g} / \mathrm{ml})$ at $28^{\circ} \mathrm{C}$ for 4 days. Again small metal blocks placed on the ends of the stripes kept the retina in contact with the substrate. Co-cultures were fixed in 4\% PFA and permeabilized with methanol $\left(-20^{\circ} \mathrm{C}\right)$. Pie-shaped segments were fixed 7 days after explanation, and stripes used in antibody pertubation experiments after 4 days. This shorter co-culture period was chosen because longer exposures to E587 Fabs affected the oligodendrocyte carpet, apparently because oligodendrocytes employ E587 antigen for the establishment and maintenance of cell-cell contacts (Bastmeyer et al., 1993). Both the smaller size of the stripe explants and the shorter co-culture period are responsible for the reduction in number of regenerating RGC axons in this assay as compared to assays with pie-shaped segments. After fixation, co-cultures were incubated with a monoclonal antibody against Gap-43 (kindly provided by Pate Skene and David Schreyer) overnight at $4^{\circ} \mathrm{C}$. After three washes in PBS (10 $\mathrm{min}$ each) cultures were treated with rhodamine (TRITC)-conjugated goat antimouse secondary antibody (Dianova) and mounted in a mixture of Mowiol (Hoechst), PBS and glycerol with n-propyl-gallate as an anti-fading agent. Outgrowing rat retinal axons were counted and measured with a cali brated eyepiece with a fluorescence microscope (Zeiss Axiophot) using the appropriate filter set.

\section{RESULTS \\ E 587 Antigen Is Upregulated by Glial Cells After Lesion of the Optic Nerve}

In the normal goldfish optic nerve/tract, antibodies against E587 antigen selectively recognize the small bundles of young growing axons originating from newborn ganglion cells at the retinal margin (Vielmetter et al., 1991; Bastmeyer et al., 1995), and do not bind to glial cells. After the optic nerve is transected (optic nerve section, ONS) E587-immunostained structures disappear from the brain side portion of the optic nerve/tract until regenerating RGC axons, which are immunopositive (Viel metter et al., 1991), cross the site of lesion. Regenerating axons enter the brain sidenerve about 6 days after ONS, increase steadily in number and re-innervate the optic tectum 10-12 days after ONS (Stuermer and Easter, 1984).

We were able to identify E587-positive glial cells in the optic tract 12 days after ONS, when the density of immunoreactive axons is still low. Later, it is increasingly difficult to distinguish glial cell profiles as the regenerating RGC axons fill the optic nerve/tract. To circumvent this problem, expression of E587 antigen by glial cells was analyzed in nerves/tracts of fish deprived of RGC axons by removing the retina. Also, in situ hybridization assays using an E587 antisense cRNA probe were performed on optic nerve/tracts in fish with regenerating RGC axons at various times after ONS.

In nerve/tracts devoid of regenerating RGC axons, E587 immunostained glial cells were found at 7 days post-ONS and their numbers increased progressively. In some sections, label ed glia cell somata giving rise to 
long processes could be seen (Fig. 1). These resembled ol igodendrocytes in culture which are known to express the E 587 antigen (Bastmeyer et al., 1993). Labeled gl ial cells were no longer discernible at 37 days because immunopositive axons from other sources-most likely the tectum-grew into the nerve.

In situ hybridizations with an E587 antisense cRNA probe revealed a large number of labeled glial cells throughout the lesioned optic nerve/tract. In the normal nerve/tract, only a few cells of unknown identity at the border of the nucleus rotundus were labeled ( $F i g$. 2A). Glial cells expressing E587 mRNA were first observed 5 days after ONS in both the eye side and brain side portion of the optic nerve/tract. The number of label ed cells reached a maximum at 14 days (F ig. 2B), began to decline at 26 days and were no longer identifiable 42 days after ONS. Although the E587-positive and mRNA expressing cells were quite abundant, they al ways represented a fraction of the many cells present in the lesioned nerve/tract. These results demonstrate that glial cells in the lesioned goldfish optic nerve/tract upregulate E587 antigen during the period of maximum RGC axon regeneration.

As mentioned above, the elongated shape of E587positive glial cells in vivo is remiscent of oligodendrocytes in vitro which carry E587 antigen on their surface and support axon growth. However, astrocytes in mixed glial cultures are also E587-positive (Bastmeyer et al., 1993), although they are not suitable substrates for growing axons. The glial cells in vivo which express E587 antigen may therefore represent either astrocytes or oligodendrocytes or both. E587 positive ol igodendrocytes are transiently anti-GFAP immunoreactive (Bastmeyer et al., 1991), so the GFAP antibodies cannot be used to distinguish "dedifferentiated" oligodendrocytes from astrocytes. Moreover, antibodies against myelin marker proteins stain the abundant degenerating myelin obscuring individual cells. To determine whether E587 antigen is expressed by oligodendrocytes in vivo, E587-immunostained vibratome sections of lesioned nerve/tracts at 12 days after ONS were examined in the electron microscope. HRP-conjugated avidin coupled secondary antibodies and DAB were used to visualize bound MAbE587.

In normal nerves, the electron-dense HRP/DAB reaction product was found exclusively on unmyelinated axons-the young and growing axons from newborn RGCs-which typically were associated in fascicles (Fig. 3). Myelinated axons and glial cells were not labeled. Twelve days after ONS, however, HRP/DAB reaction product is seen on glial cells. Labeled cells were a fraction of the many cells present and displayed ultrastructural features typical of oligodendrocytes (Wolburg, 1981; Remahl and Hildebrand, 1990; Maggs and Scholes, 1990; Strobel and Stuermer, 1994). As exemplified in Figure 4, they have an el ectron-dense cytoplasmic rim around an electron-dense nucleus with patchy chromatin. The abundant filaments and prominent desmosomes typical of fish optic nerve astrocytes (Maggs and Scholes, 1990) are not seen in these cells (Fig. 4).
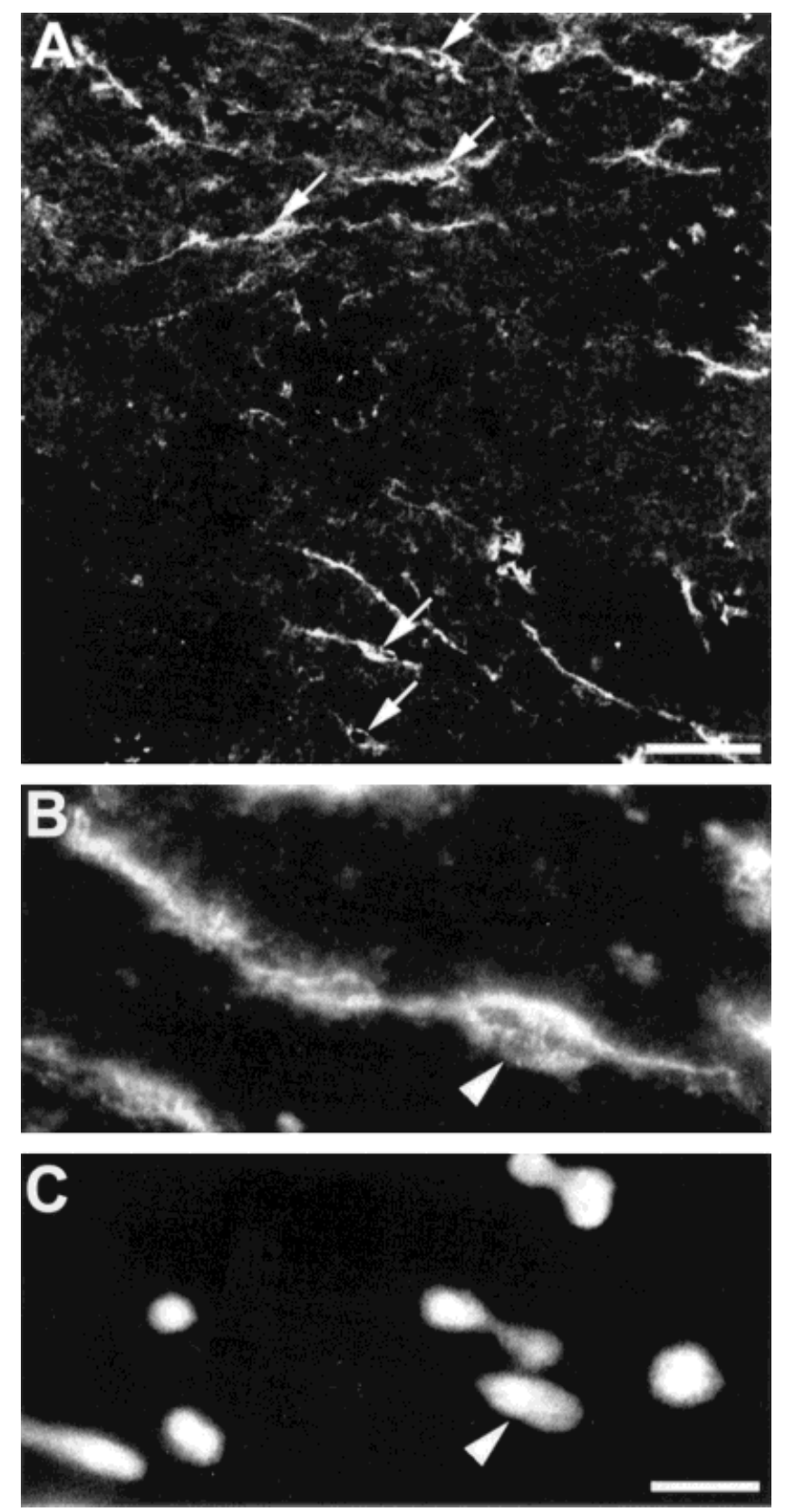

Fig. 1. E587 immunopositive glial cells in the axon-deprived optic nerve/tract. A: After removal of the retina, E587-positive glial cells are visible in the optic nerve/tract (arrows). The cells are elongated and possess long processes. B: An individual E 587-positive cell at a higher magnification. The arrowhead points to the nucleus shown in $\mathbf{C}$. C: The nuclei of the glial cells are visualized by DAPi and the arrowhead identifies the nucleus of the E 587-positive cell depicted in B. Scale bar: A: $30 \mu \mathrm{m} ; C$ applies also to $B$ : $10 \mu \mathrm{m}$.

There are also label ed cells of medium electron density with an organelle-rich cytoplasm exhibiting many free ribosomes and mitochondria (Fig. 5A) as has been observed in goldfish oligodendrocytes in vitro (Bastmeyer et al., 1993) and in vivo (Strobel and Stuermer, 1994). These cells resemble the so-called "reactive" oligodendrocytes depicted in Strobel and Stuermer (1994). 

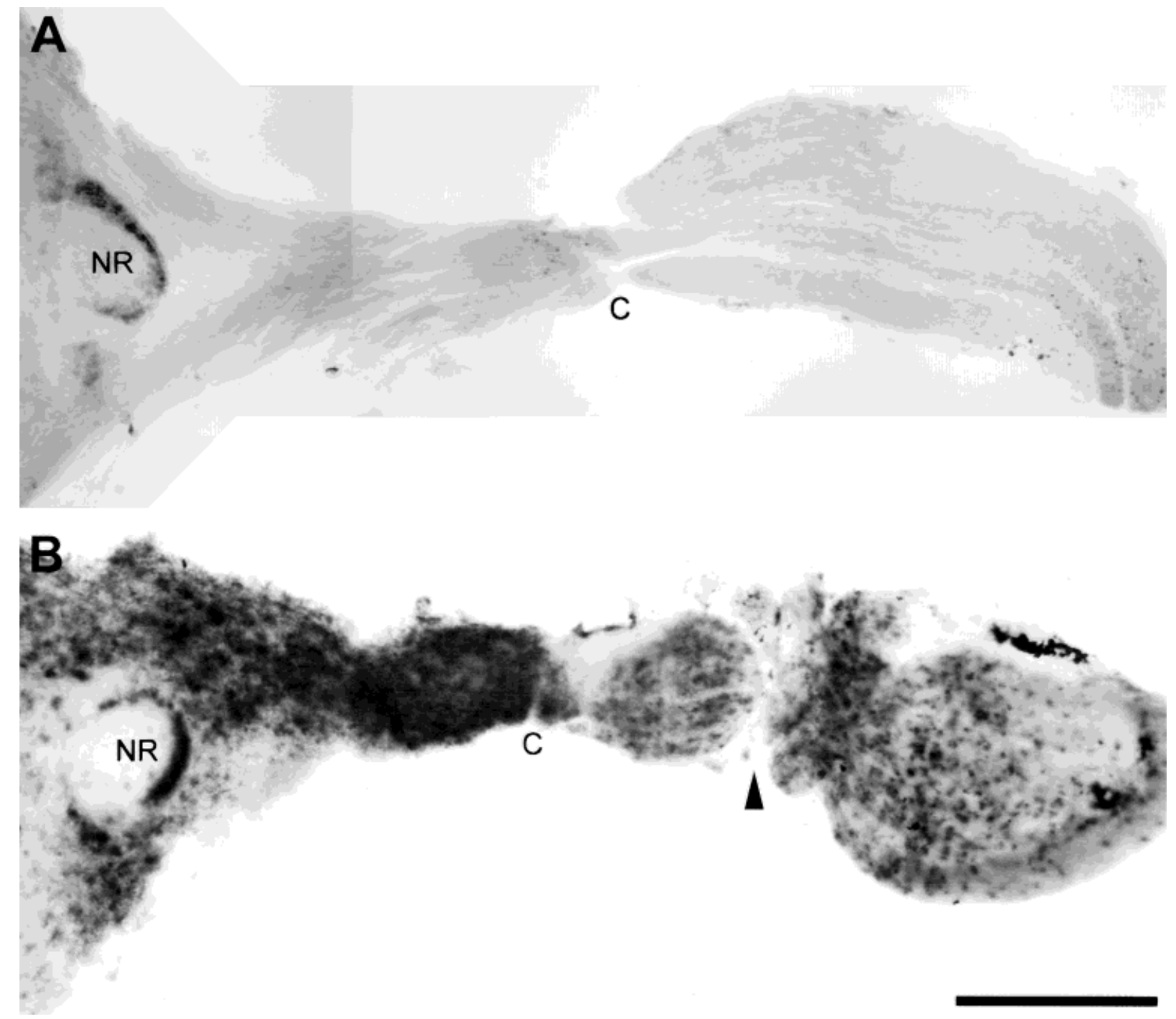

Fig. 2. Lesion-induced upregulation of E587 antigen mRNA by glial cells. A: In situ hybridization with an E587 antigen specific CRNA probe on longitudinal sections of the goldfish optic nerve/tract illustrates that the intact optic nerve/tract contains no E587 antigen mRNA expressing cells. The only cells expressing mRNA are around

the nucleus rotundus (NR). The brown-blue dots in the optic nerve (to the right) and the chiasm (C) are pigment. B: The optic nerve/tract 14 days after ONS contains numerous mRNA expressing cells. Arrowhead points to the site of lesion. Scale bar: $400 \mu \mathrm{m}$.

For the identification of E587-labeled structures, counterstaining with uranyl acetate and lead were omitted, so that organelles and other cellular features are less distinct than in conventional electron microscopi c images. Still, astrocyte processes could be clearly recognized. These astrocyte processes may possess surface label where in contact with E587-positive axon profiles, but outside these regions, and in particular at astrocyte-astrocyte contact zones, no label was present (Fig. 5B). A similar phenomenon has been observed in the mouse optic nerve (Bartsch et al ., 1989).

Consistent with the in situ hybridization and immunohistochemical light microscopic experiments, these EM results confirm that oligodendrocytes express E 587 antigen after ONS. The glial expression pattern in vivo correlates temporally with the regrowth of injured axons through the optic nerve/tract, but is not depen-

dent on the presence of regenerating axons since it was also detected in fish deprived of RGC axons, and on glia cells in culture (Bastmeyer et al., 1993).

\section{E 587 Antigen Is I nvolved in the Interaction of Goldfish Oligodendrocytes and Goldfish Retinal Axons}

We have previously shown that gol dfish oligodendrocytes are highly supportive for the growth of goldfish retinal axons (Bastmeyer et al., 1993). To test whether E587 antigen is involved in axonal growth on ol igodendrocytes, Fab fragments of a polyclonal antiserum against E587 antigen (E587 Fabs) which are known to block E587 antigen functions (Bastmeyer et al., 1995; 

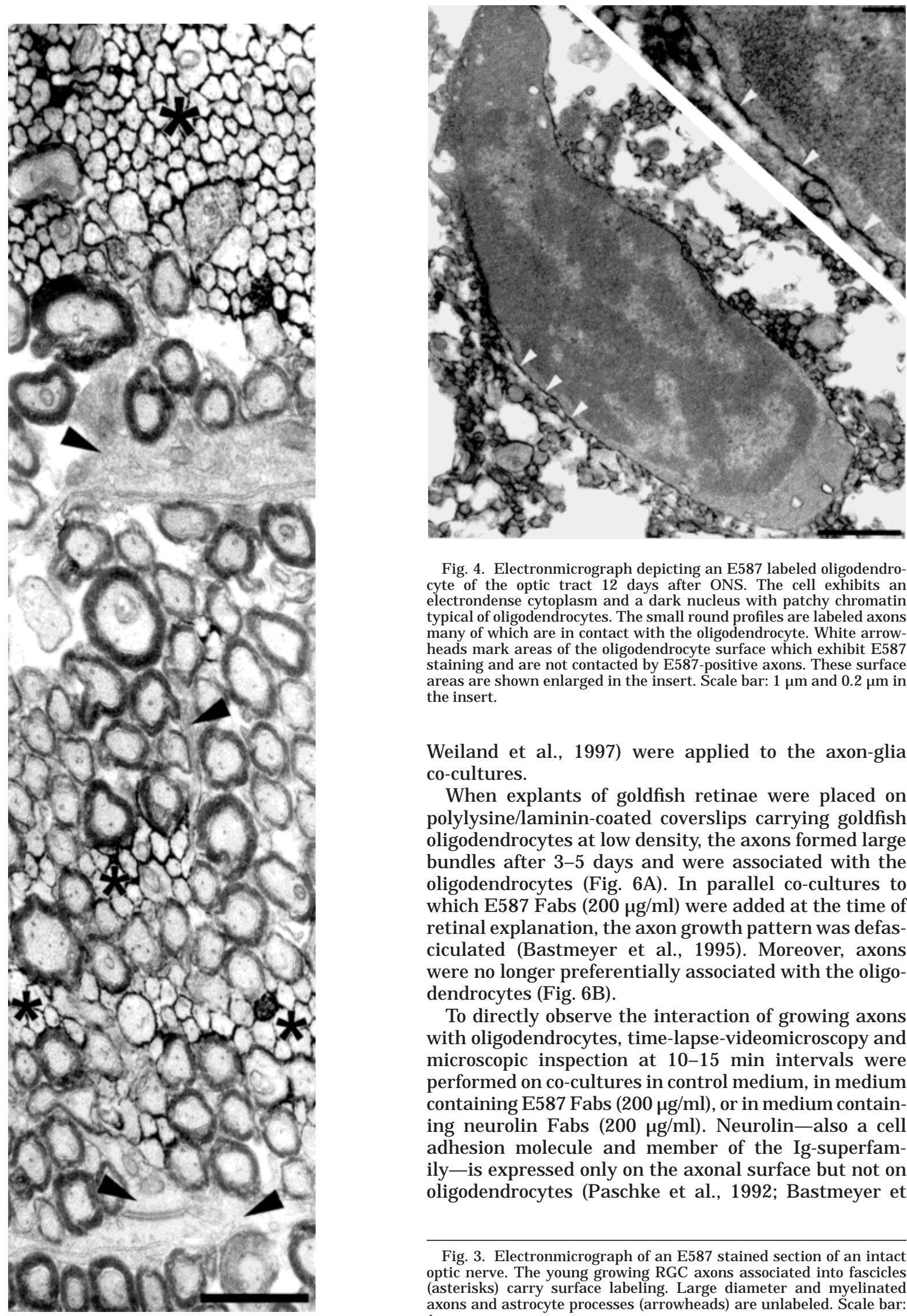

Fig. 4. Electronmicrograph depicting an E587 labeled oligodendrocyte of the optic tract 12 days after ONS. The cell exhibits an electrondense cytoplasm and a dark nucleus with patchy chromatin typical of oligodendrocytes. The small round profiles are labeled axons many of which are in contact with the oligodendrocyte. White arrowheads mark areas of the oligodendrocyte surface which exhibit E587 staining and are not contacted by E587-positive axons. These surface areas are shown enlarged in the insert. Scale bar: $1 \mu \mathrm{m}$ and $0.2 \mu \mathrm{m}$ in the insert.

Weiland et al., 1997) were applied to the axon-glia co-cultures.

When explants of goldfish retinae were placed on polylysine/laminin-coated coverslips carrying goldfish oligodendrocytes at low density, the axons formed large bundles after 3-5 days and were associated with the oligodendrocytes (Fig. 6A). In parallel co-cultures to which E $587 \mathrm{Fabs}(200 \mu \mathrm{g} / \mathrm{ml})$ were added at the time of retinal explanation, the axon growth pattern was defasciculated (Bastmeyer et al., 1995). Moreover, axons were no longer preferentially associated with the oligodendrocytes (Fig. 6B).

To directly observe the interaction of growing axons with oligodendrocytes, time-lapse-videomicroscopy and microscopic inspection at 10-15 min intervals were performed on co-cultures in control medium, in medium containing E $587 \mathrm{Fabs}(200 \mu \mathrm{g} / \mathrm{ml})$, or in medi um containing neurolin Fabs $(200 \mu \mathrm{g} / \mathrm{ml})$. Neurolin-also a cell adhesion molecule and member of the Ig-superfamily-is expressed only on the axonal surface but not on oligodendrocytes (Paschke et al., 1992; Bastmeyer et

Fig. 3. Electronmicrograph of an E587 stained section of an intact optic nerve. The young growing RGC axons associated into fascicles (asterisks) carry surface labeling. Large diameter and myelinated axons and astrocyte processes (arrowheads) are unlabeled. Scale bar: $1 \mu \mathrm{m}$. 


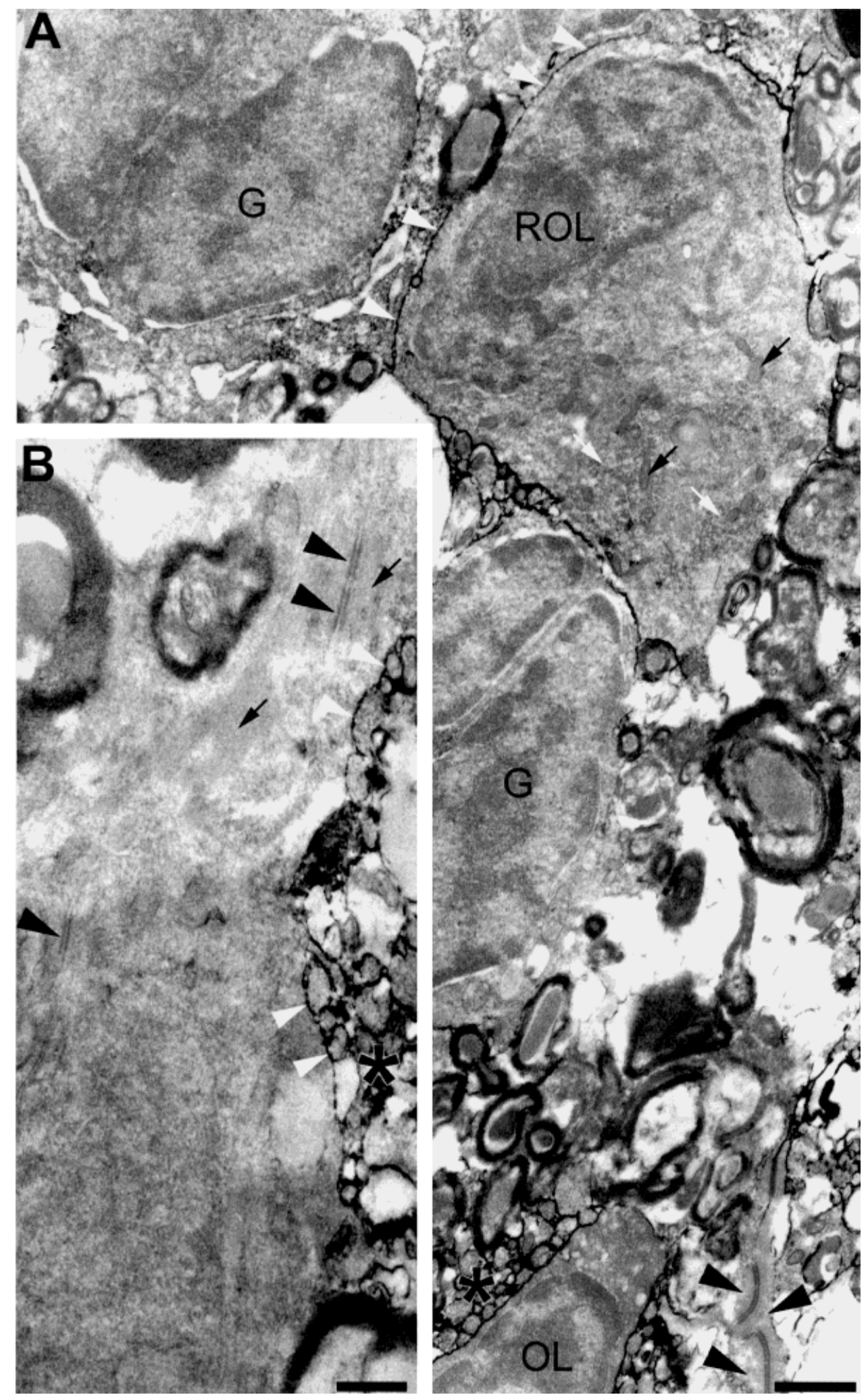

Fig. 5. Electronmicrograph illustrating E 587 label ed and unlabel ed glial cells in optic nerve 12 days after ONS. A: The so-called reactive oligodendrocyte (ROL) with medium dark cytoplasm carries E587 staining over its entire surface. Black arrows point to mitochondria and white arrows to clusters of ribosomes. The oligodendrocyte $(\mathrm{OL})$ is al so labeled. Other glial cells (G) do not possess E 587 surface staining. Astrocyte processes with desmosomes (black arrowheads) are not label ed except where contacted by E587 antigen expressing axons (B).

The asterisk shows the position of one of several bundles of axons. Dark irregular profiles are degenerating myelin and axons. B: Astrocyte processes identified by strands of filaments (arrows) and desmosomes (black arrowheads) do not exhibit E587 staining at cell-cel contact sites but staining is seen where axons (a bundle of which is marked by an asterisk) are associated with one of the astrocyte processes (white arrowheads). Scale bar: A: $1 \mu \mathrm{m} ; \mathrm{B}: 0.5 \mu \mathrm{m}$. 

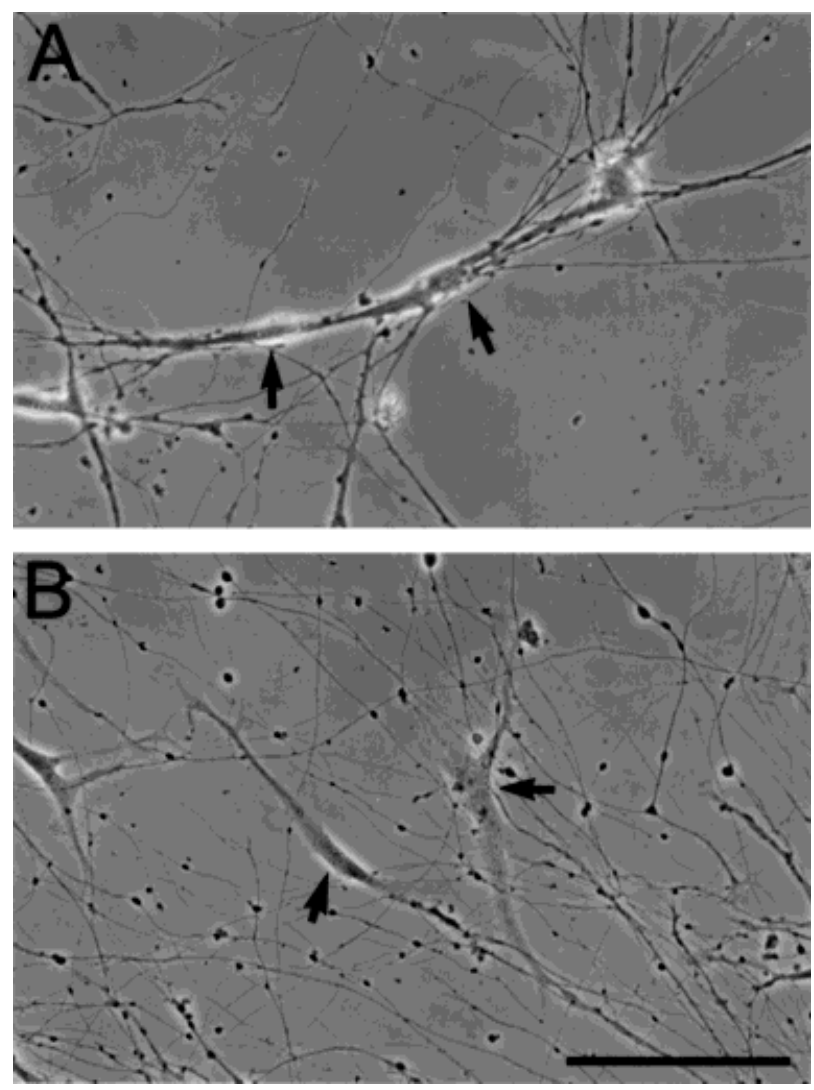

Fig. 6. Cocultures of goldfish retinal axons and gol dfish ol igodendrocytes in phase contrast. A: After 4 days in control medium (no Fabs added) the axons form fascicles and are associated with the oligodendrocytes. B: In the presence of E587 Fabs, axons are defasciculated and no longer associated with the oligodendrocyte surface. Arrows point to oligodendrocytes. Scale bar: $100 \mu \mathrm{m}$.

al., 1994). Neurolin Fabs bind to RGC axons and serve as a control to test whether binding of Fabs may perturb axon growth. Videorecordings showed that when growth cones establish contact with an oligodendrocyte they tend to elongate preferentially al ong the glial cell surface. In control medium, $72.7 \%$ (48 of 66 ) of the growth cones changed their direction when they encountered the cell or a cellular process and continued to el ongate on the ol igodendrocyte surface for at least 1 h (Fig. 7A-D and Fig. 8). The oligodendrocytes themselves are highly motile cells which migrate over the substrate (Vielmetter et al., 1990). Once RGC growth cones had established contacts with oligodendrocytes, they adhered to the glial cell so tightly that the axon was stretched when the oligodendrocyte moved and was forced to bend in the direction in which the oligodendrocyte advanced (Fig. 7D). In the presence of E587 Fabs, only $38.2 \%$ (18 of 47 ) adhered to the oligodendrocytes and grew along their surface: the remaining $61.8 \%$ continued toadvance on the polylysine/ laminin substrate (Fig. $7 \mathrm{E}-\mathrm{H}$ and Fig. 8). Also, the growth cone lost its contact with the oligodendrocyte when the oligodendrocyte moved away from the axon. Stretching of the RGC axons as consequence of growth cone adhesion to the migrating oligodendrocyte was rarely observed in the presence of E587 Fabs. In the presence of (control) neurolin Fabs, again $70.7 \%$ (29 of 41) of the growth cones el ongated al ong the ol igodendrocyte surface (Fig. 8) and tightly adhered even to moving cells indicating that the observed effects result from blocking the E587 antigen and not from the mere binding of $\mathrm{Fab}$ fragments to the axonal surface.

Theseresults confirm that RGC growth cone-oligodendrocyte adhesion and the preference of RGC axons for growth on goldfish of oligodendrocytes can be neutralized by antibodies against the E 587 antigen.

\section{E 587 Antigen Is Involved in the Outgrowth of Regenerating Rat Retinal Axons on Goldfish Oligodendrocytes}

As reported previously, goldfish ol igodendrocytes support the growth of regenerating rat retinal axons in vitro (Bastmeyer et al., 1993). These cross-species co-cultures require a temperature which is tolerated both by cells from coldblooded vertebrates (i.e. fish) and by the mammalian tissue, whose optimal temperature is $37^{\circ} \mathrm{C}$. The compromise temperature $\left(28^{\circ} \mathrm{C}\right)$ and the omission of $\mathrm{O}_{2} / \mathrm{CO}_{2}$ gas application (normally used for cultures of mammalian nervous tissue) results in suboptimal outgrowth from rat retinal explants on noncelluIar substrates. In spite of this, adult rat RGCs extend a substantial number of axons on goldfish oligodendrocytes. To quantify this effect, we compared the outgrowth of axons from rat retinal explants on goldfish oligodendrocytes with the outgrowth on polylysine/ laminin. After 7 days at $28^{\circ} \mathrm{C}$ on polylysine-laminincoated coverslips, the mean number of axons per retina segment was $3.6( \pm 0.8 \mathrm{SEM}$ [standard error of the mean]; $n=57$ ). On a substrate of goldfish oligodendrocytes, 19.3 ( \pm 3.5 SEM) axons per segment $(n=57)$ were found. This difference is statistically significant (Mann-Whitney U-test, $\alpha \leq 0.001$ ).

To determine if the E587 antigen is involved in the outgrowth of rat retinal axons on goldfish oligodendrocytes, E587 Fabs were applied to the co-cultures in which stripes of rat retina were explanted onto a carpet of goldfish oligodendrocytes and kept at $28^{\circ} \mathrm{C}$ for 4 days (Fig. 9). Axons were immunostained with mAb against Gap-43. The numbers of axons in control medium, in medium containing $\mathrm{Fab}$ fragments of nonimmune serum $(200 \mu \mathrm{g} / \mathrm{ml})$, and in medium containing E587 Fabs $(200 \mu \mathrm{g} / \mathrm{ml})$ were compared (Fig. 10). In control medium, the mean number was 5.5 ( \pm 1.1 SEM) axons per explant $(n=46)$. This is similar to the mean of 5.0 axons ( $\pm 0.7 \mathrm{SEM} ; \mathrm{n}=29$ explants) in medium containing nonimmune Fabs. In the presence of E587 Fabs, however, the mean was $2.5( \pm 0.5$ SEM) axons per explant $(n=47)$.

Thus, E587 antigen on goldfish oligodendrocytes apparently promotes outgrowth of regenerating RGC axons from rat retinal explants. This implies that the regenerating rat RGC axons possess the relevant molecular component(s) necessary for interactions with 

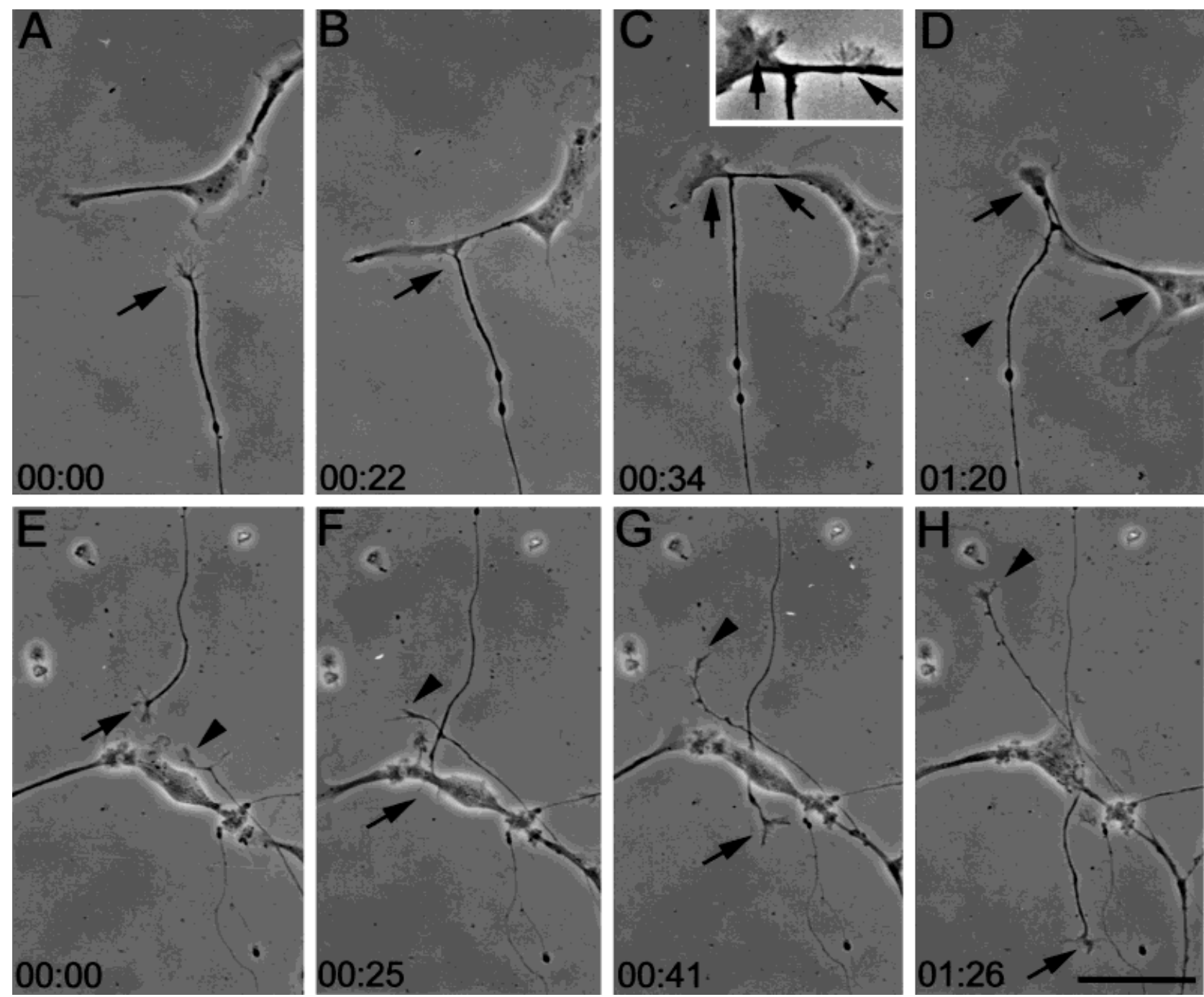

Fig. 7. Phase contrast images illustrating the behavior of goldfish retinal axons in contact with goldfish oligodendrocytes in temporal sequence. A-D: Control medium (no Fabs added). U pon contact with the oligodendrocyte the growth cone (arrow) adheres to the cell and bifurcates and both growth cones (arrows in C, and shown in higher magnification in the inset) stay in close contact with the oligodendrocyte surface over the next hour. During this time the oligodendrocyte moves to the right and carries the adhering growth cones with it

goldfish E587 antigen. One possible candidate for this role is the cell adhesion protein L1 (Bähr et al., 1988; J ung et al., 1997).

\section{DISCUSSION}

In response to optic nerve lesion, glial cells in the goldfish visual pathway upregulate the expression of the cell adhesion molecule E587 antigen. This molecule, which promotes axon growth (Bastmeyer et al., 1995; Weiland et al., 1997), is thereby available all along the path of the regenerating axons, which carry E587 antigen on their own surfaces (Vielmetter et al., 1991). (arrows in D). In consequence the axon is stretched and bends in the direction in which the cell moves (arrowhead in D). E-H: In the presences E587 Fabs, one growth cone (arrows in E, F) crosses the oligodendrocyte. A second growth cone (arrowheads in E, F) contacts the oligodendrocyte repeatedly but does not adhere to the cell's surface. The time is given in hours and minutes in the lower left corner. Scale bar: $50 \mu \mathrm{m}$.

E587-positive cells in vivo are elongated and have one or two long processes. They resemble the goldfish oligodendrocytes which express E587 antigen in vitro (Bastmeyer et al., 1993). E587 immunostaining has been observed on the surface of cells with ultrastructural features characteristic of oligodendrocytes (Maggs and Scholes, 1990; Strobel and Stuermer, 1994). This suggests an E587 antigen-dependent interaction between axons and oligodendrocytes during RGC axon regeneration in vivo. The present in vitro assays were performed with antibodies which block E587 antigen function. They illustrate that E587 antigen mediates the preferential adhesion of regenerating gol dfish RGC growth cones to oligodendrocytes and promotes the growth of fish and rat RGC axons along the glial cell 


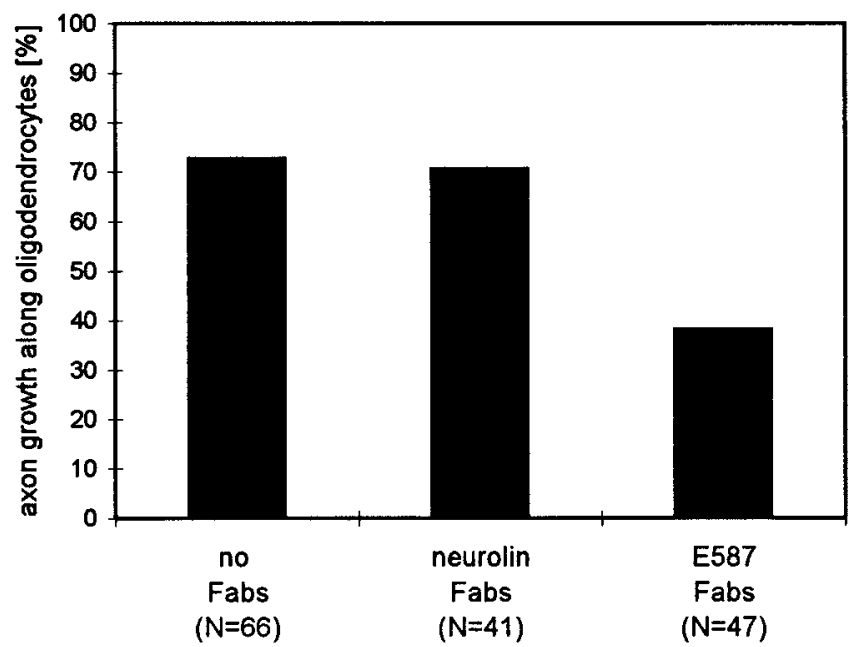

Fig. 8. Quantification of the reaction of goldfish retinal axons upon contact with goldfish oligodendrocytes. In control medium (no Fabs added) and in the presence of neurolin Fabs more than $70 \%$ of the growth cones change their direction and continue to elongate on the ol igodendrocyte surface. In contrast, in the presence of E587 F abs only $38.2 \%$ of the growth cones adhere and remain on the oligodendrocyte surface.

surface. This, together with the finding that E587 antigen production by glial cells temporally correlates with the period of axon regrowth in this system (Stuermer and Easter, 1984; Hirsch et al., 1995), implies that glia-associated E587 antigen may support RGC axon regeneration in vivo much as it does in vitro. This is consistent with observations in which individual regenerating growth cones were found in direct contact with oligodendrocytes in the goldfish optic nerve (Strobel and Stuermer, 1994).

In contrast to the intact system, glial cells in vivo express E587 mRNA and E587 antigen after the optic nerve is sectioned, when the retina is removed and when they are isolated and raised in culture (Bastmeyer et al., 1993). Optic nerve transection or retina removal separates the retinal axons from their RGC somata, leading to the degeneration of the retinal axons and to the gradual decay and phagocytosis of the myelin sheath (Springer and Wilson, 1989) that previously surrounded the axons. This suggests that deprivation of axon contact and loss of myelinating processes (and/or changes in consequence of these events) induces E 587 antigen upregulation in glial cells. In the course of these events and perhaps in response to factors secreted by microglia/macrophages (Giulian, 1984), oligodendrocytes change both their morphology and synthesis of molecular constituents. In the normal nerve/tract, oligodendrocytes myelinate axons in a manner typical of higher vertebrates (Wolburg, 1981), and express molecul es characteristic of myel inating glial cells (Waehneldt, 1990). Earlier in vitro studies showed that oligodendrocytes acquire an elongated shape, extend long processes, associated into network-like carpets, express cell adhesion proteins (E587 antigen being one of them), and exhi bit substrate properties that favor axon
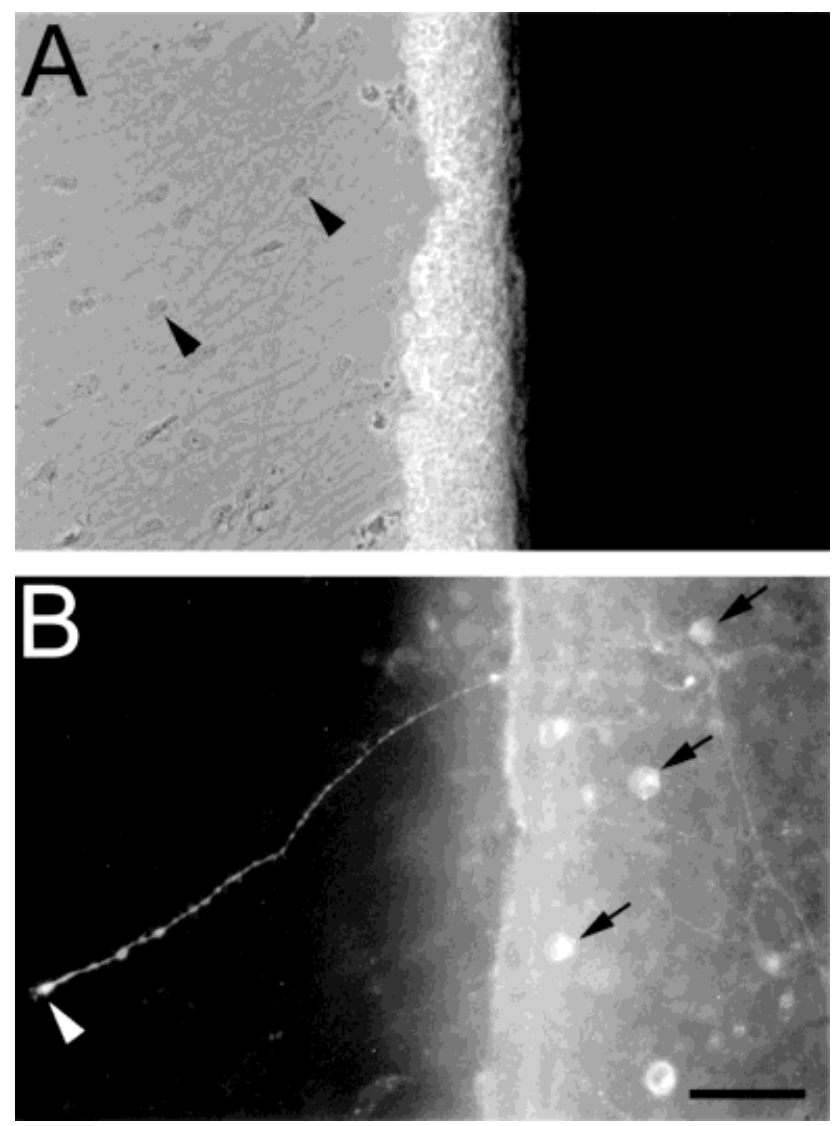

Fig. 9. Regenerating rat retinal axons growing on goldfish oligodendrocytes. A: Phase contrast image of a rat retinal explant on a uniform carpet of goldfish oligodendrocytes (arrowheads in A point to glial cell bodies). B: Corresponding immunofluorescence image depicting a Gap-43 positive regenerating rat axon (arrowhead in B points to the growth cone). The arrows point to Gap-43 positive retinal ganglion cell bodies within the explant. Scale bar: $50 \mu \mathrm{m}$.

growth (Bastmeyer et al., 1993, 1994). They are O4immunoreactive and synthesize the teleost myel in protein IP2 (J eserich and Rauen, 1990; Bastmeyer et al., 1991). They thus possess early differentiation markers of oligodendrocytes but do not produce advanced myelin markers (Bastmeyer et al., 1991) unless they are cocultured with axons (Bastmeyer et al., 1993, 1994).

The E 587-positive cells with long processes identified in axon-deprived nerves in vivo resemble oligodendrocytes in vitro (Bastmeyer et al., 1993, 1994). This suggests that E587 labeled cells of this shape are oligodendrocytes undergoing similar changes as their in vitro counterparts. Unfortunately, antibodies $\mathrm{O} 4$ (Sommer and Schachner, 1981), 6D2 (against fish IP1/2, J eserich and Rauen, 1990) and those against other myelin marker proteins (i.e. MBP, MAG) all stain the abundant myelin debris when applied to sections of the lesioned optic nerve/tract and therefore do not allow recognition of the oligodendrocytes proper. However, detection of E587 surface labeling on cells that exhibit ultrastructural characteristics of oligodendrocytes (Bastmeyer et al., 1993; Strobel and Stuermer, 1994) 


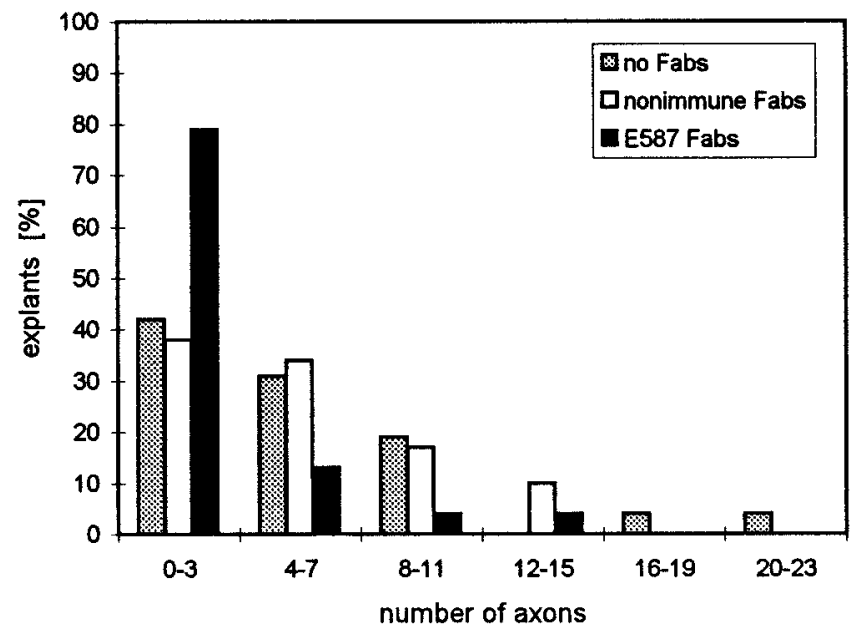

Fig. 10. Quantification of rat retinal axons per explant (stripes) on goldfish oligodendrocytes. In control medium (no Fabs) the average number of axons per explant was $5.5( \pm 1.1$ SEM $n=46$ explants) and $5.0( \pm 0.7 \mathrm{SEM} ; \mathrm{n}=29)$ in medium containing non-immune $\mathrm{Fabs}$. However, in the presence of E587 Fabs, the average number of axons fell to 2.5 ( \pm 0.5 SEM; $n=47)$ axons per explant were counted. The difference of axon numbers in the presence of E $587 \mathrm{~F}$ abs as apposed to axon numbers in the controls is statistically significant (MannWhitney U-test, $\alpha \leq 0.01$ )

confirm that E 587 antigen is produced by this type glia not only in vitro but al so in vivo.

Astrocytes may al so synthesize E 587 antigen, as they do in vitro (Bastmeyer et al., 1993). However, in ultrathin sections, E587 label was only seen where axon profiles were in contact with astrocytes but not where astrocytes were in contact with each other. It was not possibletoresolve whether the label is associated solely with the axons or whether astrocytes possess E587 antigen on their own surfaces at these sites. A similar phenomenon has been observed in the devel oping mouse optic nerve (Bartsch et al., 1989) where astrocytes showed L 1 sel ectively at axon-gl ia contact sites. Consistent with our results, mouse astrocytes (Bartsch et al., 1989) were not labeled outside of these regions. Still, it is conceivable that E587 antigen is involved in RGC axon-astrocyte interactions in vivo.

In mixed glial cell cultures, fish astrocytes associate into separate clusters and are avoided by growing RGC axons which instead prefer to el ongate over oligodendrocytes (Bastmeyer et al., 1993). Astrocytes in vivo normally partition the optic nerve into distinct fascicles, synthesize a basal lamina around the fascicles, penetrate between the axons and contact nodes of Ranvier (Maggs and Scholes, 1986). The fascicle "units" are retained in lesioned nerves, indicating that astrocytes maintain contacts with one another. They increase synthesis of GFAP and other cytoskeletal proteins (Maggs and Scholes, 1986, 1990; Giordano et al., 1989; Stafford et al., 1990). In the optic tract, astrocytes are more loosely arranged and span the width of the tract like radial glial cells (Levine, 1991). The changes that they undergo upon lesion have not been analyzed. The emphasis here is on oligodendrocytes.
Oligodendrocytes in fish apparently possess a degree of plasticity comparable to that seen in the amphibian visual system (Lang and Stuermer, 1996). They resemble Schwann cells in that they dedifferentiate and proliferate in vitro and respond to deprivation of axons by synthesizing cell adhesion proteins as well as growth factors. Goldfish oligodendrocytes produce the so-called axogenesis factors which stimulate the upregulation of growth-associated proteins (Tabibiazar et al., 1997) in isolated fish retinal gangl ion cells (Schwalb et al ., 1995, 1996). Mammalian Schwann cells are known to express L1, to support adhesion and growth of L1-positive axons (Seilheimer and Schachner, 1988) and to accumulate $L 1$ at axon-Schwann cell contact sites (Martini et al., 1994). The E 587 antigen associated with oligodendrocytes has similar functions and pattern of distribution. Also, like Schwann cells (Wood et al., 1990a,b) fish oligodendrocytes in long term co-cultures begin to ensheath axons which have previously elongated along their surfaces (Bastmeyer et al., 1993). They properly remyel inate regenerated RGC axons in vivo (Wolburg, 1981) and thus contribute to the repair of lesioned CNS fiber tracts as Schwann cells do in the mammalian peripheral nervous system (reviewed in Fawcett and Keynes, 1990). This "adaptive plasticity" of Schwann cells and goldfish oligodendrocytes correlates with and may be causally linked to successful axon regeneration and the functional restoration of fiber tracts (Lang and Stuermer, 1996) which occurs in the PNS of mammals, and in both the PNS and CNS of fish.

Oligodendrocytes in fish further differ from their mammalian counterparts in that they apparently lack the mol ecular components which block axon regrowth, as well as the neurite-growth inhibitors that evoke growth cone collapse (Bandtlow et al., 1990, 1993). Fish CNS myelin is growth permissive for both fish and mammalian neurons (Bastmeyer et al., 1991; Wanner et al., 1995), and both rat and fish RGC axons can regenerate along the surface of fish oligodendrocytes (Bastmeyer et al., 1993). E587 antigen is one of the surface proteins that support axon growth along these cells. The observed adhesion of fish RGC growth cones to fish oligodendrocytes and their preference for further extension along the oligodendrocyte processes can be attributed to the interaction of the E587 antigen on axons with the E587 antigen on glial cells. It suggests that this results from homophilic interaction. This is consistent with earlier results (Bastmeyer et al., 1995; Weiland et al., 1997) and the notion that L1-like CAMs effect downstream events and axon growth (Brümmendorf and Rathjen, 1994; Doherty and Walsh, 1994; Kamiguchi and Lemmon, 1997).

This E587 antigen interaction may not be the only factor effecting axon growth and axon-oligodendrocyte adhesion. Other CAMs (and their heterophilic interactions) (Brümmendorf and Rathjen, 1994) and other molecular components may al so be invol ved. NCAM, for instance, is present on RGC axons (Bastmeyer et al., 1990) and fish oligodendrocytes (Bastmeyer et al., 1994), but a functional analysis of the role of NCAM in 
this system is not available. mRNAs of NCAM and of members of the L 1 family, i.e., L 1.1 and L 1.2 (Tongiorgi et al., 1995), have been observed in glial cells in lesioned optic nerves of zebrafish (Bernhard et al., 1996), implying that the corresponding proteins support axon regeneration. These observations in zebrafish and our present findings in goldfish are consistent with the view that upregulation of CAMs is advantageous for axon regeneration.

The outgrowth-promoting effect of gol dfish oligodendrocytes on rat RGCs observed in earlier cross species co-cultures (Bastmeyer et al., 1993) was functionally assessed and shows that axon growth is reduced in the presence of E587 Fabs. This indicates that the E587 antigen associated with goldfish oligodendrocytes is recognized by rat RGCs and can influence their growth. Whether $L 1$ on regenerating rat RGC axons (Bähr et al., 1988; J ung et al., 1997) binds to the L1-like E587 glycoprotein, and whether other CAMs on rat axons are involved cannot be determined from our current data. It is also not known if there is a direct homolog of E587 antigen in rats. The polyclonal E587 antiserum and the Fabs derived from this serum weakly stain the regenerating rat RGC axons and recognize protein bands on Western blots (Petrausch and Stuermer, unpublished observations), which suggests that it reacts with $L 1$. It is impossible to decide at present whether E587 Fabs functionally block L1 or L1-related proteins on rat neurons, but E $587 \mathrm{Fab}$ application blocks E587 antigen on the oligodendrocyte surface and significantly reduces the number of rat axons compared to those found on fish oligodendrocytes in control experiments.

E587 antigen is not only involved in axon-oligodendrocyte interaction, but apparently also in the interaction among oligodendrocytes, at least in culture. E587 antigen is accumulated at ol igodendrocyte-oligodendrocyte contact sites (Bastmeyer et al., 1993, 1994). E 587 Fabs prevent the association of oligodendrocytes into network-like carpets. This hinders the investigation of axon growth on oligodendrocyte carpets in the presence of E587 Fabs for more than 3-4 days, and prevents experiments with long-term cultures in which one may wish to test whether E587 antigen participates in the ensheathment of RGC axons observed earlier (Wood et al., 1990a,b; Bastmeyer et al., 1993).

The behavior of oligodendrocytes in vitro and in vivo indicates that these cells can alter their properties depending on the state of the system. They changetheir function from axon-myelination to growth support and back again. Whether an individual oligodendrocyte performs these tasks in sequence or whether undifferentiated precursor cells are recruited after optic nerve lesion to produce E587 antigen and remyel inate axons is currently being investigated (Ankerhold et al., 1997).

\section{ACKNOWLEDGMENTS}

The authors thank Mary Ann Cahill for help with the electronmicroscopic analyses and for correcting the
English and Stefan Höger for hel $p$ with the time-lapse recordings.

R.A. is fellow of the Boehringer Ingelheim Fonds. This work is supported by grants of the DFG (SFB 156) to C.A.O.S.

\section{REFERENCES}

Ankerhold, R., Leppert, C.A., Bastmeyer, M., and Stuermer, C.A.O. (1997) Adaptive plasticity of goldfish oligodendrocytes during retinal axon regeneration. Soc. Neurosci. Abstr., 23.

Bähr, M., Vanselow, J ., and Thanos, S. (1988) In vitro regeneration of adult rat ganglion cell axons from retinal explants. Exp. Brain Res. 73:393-401.

Bähr, M., and Bonhoeffer, F. (1994) Perspectives on axonal regeneration in the mammalian CNS. Trends Neurosci., 17:473-479.

Bandtlow, C., Zachleder, T., and Schwab, M.E. (1990) Oligodendrocytes arrest neurite growth by contact inhibition. J. Neurosci. 10:3837-3848.

Bandtlow, C.E., Schmidt, M.F., Hassinger, T.D., Schwab, M.E., and Kater, S.B. (1993) Role of intracellular calcium in NI-35-evoked collapse of neuronal growth cones. Science, 259:80-83.

Bartsch, U. Kirchhoff, F., and Schachner, M. (1989) Immunohistochemical localization of the adhesion molecules L1, N-CAM, and MAG in the developing and adult optic nerve of mice. J. Comp. Neurol., 284:451-462.

Bastmeyer, M., Schlosshauer, B., and Stuermer, C.A.O. (1990) The spatiotemporal distribution of N-CAM in the retinotectal pathway of adult goldfish detected by the monoclonal antibody D3. Development, 108:299-311.

Bastmeyer, M., Beckmann, M., Schwab, M.E., and Stuermer, C.A.O (1991) Growth of regenerating goldfish axons is inhibited by rat oligodendrocytes and CNS myelin but not by goldfish optic nerve tract oligodendrocytelike cells and fish CNS myelin. J . Neurosci. 11:626-640.

Bastmeyer, M., Bähr, M., and Stuermer, C.A.O. (1993) Fish optic nerve oligodendrocytes support axonal regeneration of fish and mammalian retinal ganglion cells. GLIA, 8:1-12.

Bastmeyer, M., J eserich, G., and Stuermer, C.A.O. (1994) Similarities and differences between fish oligodendrocytes and schwann cells in vitro. GLIA, 11:300-314.

Bastmeyer, M., Ott, H., Leppert, C.A., and Stuermer, C.A. (1995) Fish E587 glycoprotein, a member of the L1 family of cell adhesion molecules, participates in axonal fasciculation and the age-related order of ganglion cell axons in the goldfish retina. J. Cell Biol., 130:969-976.

Bernhardt, R.R., Tongiorgi, E., Anzini, P., and Schachner, M. (1996) Increased expression of specific recognition molecules by retinal ganglion cells and by optic pathway glia accompanies the successful regeneration of retinal axons in the adult zebrafish. J. Comp. Neurol., 376:253-264.

Brümmendorf, T., and Rathjen, F., eds. (1994) Cell Adhesion Molecules. 1. I mmunogl obulin Superfamily. Academic Press, London.

Bunge, R.P., and Hopkins, J.M. (1990) The role of peripheral and central neuroglia in neural regeneration in vertebrates. Semin. Neurosci., 2:509-518.

Doherty, P., and Walsh, F.S. (1994) Signal transduction events underlying neurite outgrowth stimulated by cell adhesion molecules. Curr. Opin. Neurobiol., 4:49-55.

Fawcett, J .W. (1992) Intrinsic neuronal determinants of regeneration. TINS, 15:5-8.

Fawcett, J .W., and Keynes, R.J . (1990) Peripheral nerve regeneration. Annu. Rev. Neurosci., 13:43-60.

Fu, S.Y., and Gordon, T. (1997) The cellular and molecular basis of peripheral nerve regeneration. Mol. Neurobiol., 14:47-116.

Gaze, R.M. (1970) The Formation of Nerve Connections. Academic Press, London.

Giordano, S., Glasgow, E., Tesser, P., and Schechter, N . (1989) A type II keratin is expressed in glial cells of the goldfish visual pathway. Neuron, 2:1507-1516.

Giordano, S., Laessing, U., Ankerhold, R., Lottspeich, F., and Stuermer, C.A. (1997) Molecular characterization of E 587 antigen: An axonal recognition molecule expressed in the goldfish central nervous system. J . Comp. Neurol., 377:286-297.

Giulian, D. (1984) Peptides from the regenerating central nervous system of goldfish stimulate glia. Proc. Natl. Acad. Sci. U.S.A., 81:3567-3571. 
Hirsch, S., Cahill, M.A., and Stuermer, C.A. (1995) Fibroblasts at the transection site of the injured goldfish optic nerve and their potential role during retinal axonal regeneration. J . Comp. Neurol., 360:599-611.

Hortsch, M. (1996) The L1 family of neural cell adhesion molecules: Old proteins performing new tricks. Neuron, 17:587-593.

J eserich, G., and Rauen, T. (1990) Cell cultures enriched in oligodendrocytes from the central nervous system of trout in terms of phenotypic expression exhibit parallels with cultured rat Schwann cells. GLIA, 3:65-74.

J ung, M., Petrausch, B., and Stuermer, C.A. (1997) Axon-regenerating retinal ganglion cells in adult rats synthesize the cell adhesion molecule L 1 but not TAG-1 or SC-1. Mol. Cell. Neurosci., 9:116-131.

Kamiguchi, H., and Lemmon, V. (1997) Neural cell adhesion molecule L 1: Signaling pathways and growth cone motility. J . Neurosci. Res., 49:1-8.

Laessing, U., Giordano, S., Stecher, B., Lottspeich, F., and Stuermer, C.A.O. (1994) Molecular characterization of fish neurolin: A growthassociated cell surface protein and member of the immunoglobulin superfamily in the fish retinotectal system with similarities to chick protein DM-GRASP/SC-1/BEN. Differentiation, 56:21-29.

Lang, D.M., and Stuermer, C.A. (1996) Adaptive plasticity of Xenopus glial cells in vitro and after CNS fiber tract lesions in vivo. GLIA, 18:92-106.

Levine, R.L. (1991) Gliosis during optic fiber regeneration in the gol dfish: An immunohistochemical study. J . Comp. Neurol., 312:549560.

Maggs, A., and Scholes, J. (1986) Glial domains and nerve fiber patterns in the fish retinotectal pathway. J . Neurosci., 6:424-438.

Maggs, A., and Scholes, J. (1990) Reticular astrocytes in the fish optic nerve: Macroglia with epithelial characteristics form an axially repeated lacework pattern, to which nodes of Ranvier are apposed. J. Neurosci., 10:1600-1614.

Martini, R., and Schachner, M. (1986) Immunoelectron microscopic localization of neural cell adhesion molecules ( $L 1, N-C A M$, and MAG) and their shared carbohydrate epitope and myelin basic protein in devel oping sciatic nerve. J . Cell Biol., 103:2439-2448.

Martini, R., Xin, Y., and Schachner, M. (1994) Restricted localization of L1 and N-CAM at sites of contact between Schwann cells and neurites in culture. GLIA, 10:70-74.

Paschke, K.A., Lottspeich, F., and Stuermer, C.A.O. (1992) Neurolin, a cell surface glycoprotein on growing retinal axons in the goldfish visual system, is reexpressed during retinal axonal regeneration. J . Cell Biol., 117:863-875.

Reier, P.J ., and Houlé, J .D. (1988) The glial scar: Its bearing on axonal elongation and transplantation approaches to CNS repair. Adv. Neurol., 47:87-138.

Remahl, S., and Hildebrand, C. (1990) Relation between axons and oligodendroglial cells during initial myelination. I. The glial unit. J . Neurocytol ., 19:313-328.

Scherer, S.S., and Easter, S.S., J r. (1984) Degenerative and regenerative changes in the trochlear nerve of goldfish. J. Neurocytol., 13:519-565.

Schwab, M.E., Kapfhammer, J .P., and Bandtlow, C.E. (1993) Inhibitors of neurite growth. Ann. Rev. Neurosci., 16:565-595.

Schwalb, J .M., Boulis, N.M., Gu, M.G., Winickoff, J ., J ackson, P.S. Irwin, N., and Benowitz, L.I. (1995) Two factors secreted by the goldfish optic nerve induce retinal ganglion cells to regenerate axons in culture. J. Neurosci., 15:5514-5525.

Schwalb, J.M., Gu, M.-F., Stuermer, C.A.O., Bastmeyer, M., Hu, G.-F. Boulis, N., I rwin, N., and Benowitz, L.I. (1996) Optic nerve glial secrete a low-molecular-weight factor that stimulates retinal ganglion cells to regenerate axons in the goldfish. Neuroscience, 72:901910.
Seilheimer, B., and Schachner, M. (1988) Studies of adhesion molecules mediating interactions between cells of peripheral nervous system indicate a major role for L1 in mediating sensory neuron growth on Schwann cells in culture. J . Cell Biol., 107:341-351.

Sommer, I., and Schachner, M. (1981) Monoclonal antibodies (O1 to O4) to ol igodendrocyte cell surfaces: An immunocytological study in the central nervous system. Dev. Biol., 83:311-327.

Springer, A.D., and Wilson, B.R. (1989) Light microscopic study of degenerating cobalt-filled optic axons in goldfish: Role of microglia and radial glia in debris removal. J . Comp. Neurol., 282:119-132.

Stafford, C.A., Shehab, S.A.S., Nona, S.N., and Cronly-Dillon, J.R. (1990) Expression of glial fibrillary acidic protein (GFAP) in gol dfish optic nerve fol lowing injury. GLIA, 3:33-42.

Strobel, G., and Stuermer, C.A.O. (1994) Growth cones of regenerating retinal axons contact a variety of cellular profiles in the transected goldfish optic nerve. I. Comp. Neurol., 346:435-448.

Stuermer, C.A.O., and Easter, S.S.J. (1984) A comparison of the normal and regenerated retinotectal pathways of goldfish. J . Comp. Neurol., 223:57-76.

Stuermer, C.A.O., Bastmeyer, M., Bähr, M., Strobel, G., and Paschke, $K$. (1992) Trying to understand axonal regeneration in the CNS of fish. J . Neurobiol., 23:537-550.

Tabibiazar, R., I win, N., Petrausch, R., Torron, J ., J ing, Y., Stuermer, C.A.O., and Benowitz, L.I. (1997) Axogenesis factor-3, secreted by goldfish optic nerve, induces axonal regeneration in lower vertebrate and mammalian neurons. Soc. Neurosci. Abstr., 23.

Tongiorgi, E., Bernhardt, R.R., and Schachner, M. (1995) Zebrafish neurons express two L 1-related molecules during early axonogenesis. J. Neurosci. Res. 42:547-561.

Vielmetter, J., and Stuermer, C.A. (1989) Goldfish retinal axons respond to position-specific properties of tectal cell membranes in vitro. Neuron, 2:1331-1339.

Vielmetter, J ., Stolze, B., Bonhoeffer, F., and Stuermer, C.A.O. (1990) In vitro assay to test differential substrate affinities of growing axons and migratory cells. Exp. Brain Res., 81:283-287.

Vielmetter, I., Lottspeich, F., and Stuermer, C.A.O. (1991) The monoclonal antibody E587 recognizes growing (new and regenerating) retinal axons in the goldfish retinotectal pathway. J. Neurosci. 11:3581-3593.

Waehneldt, T.V. (1990) Phylogeny of myelin proteins. Ann. N.Y. Acad. Sci., 605:15-28.

Wanner, M., Lang, D.M., Bandtlow, C.E., Schwab, M.E., Bastmeyer, M., and Stuermer, C.A.O. (1995) Reevaluation of the growthpermissive substrate properties of goldfish optic nerve myelin and myelin proteins. J . Neurosci., 15:7500-7508.

Weiland, U.M. Ott, H. Bastmeyer, M., Schaden, H., Giordano, S., and Stuermer, C.A. (1997) Expression of an L1-related cell adhesion molecule on developing CNS fiber tracts in zebrafish and its functional contribution to axon fasciculation. Mol. Cell. Neurosci., 9:77-89.

Westerfield, M., ed. (1994) The Zebrafish Book: A Guide for the Laboratory Useof Zebrafish (Brachydanio rerio), ed. 2.1. Institute of Neuroscience, University of Oregon, Eugene.

Wilkinson, D.G. (1992) In Situ Hybridization, A Practical Approach. IRL Press at Oxford University Press, Oxford.

Wolburg, H. (1981) Myelination and remyel ination in the regenerating visual system of the goldfish. Exp. Brain. Res., 43:199-206.

Wood, P., Moya, F., Eldridge, C., Owens, G., Ranscht, B., Schachner, M., Bunge, M., and Bunge, R. (1990a) Studies of the initiation of myelination by Schwann cells. Ann. N. Y. Acad. Sci., 605:1-14.

Wood, P.M., Schachner, M., and Bunge, R.P. (1990b) Inhibition of Schwann cell myelination in vitro by antibody to the $L 1$ adhesion molecule. J . Neurosci., 10:3635-3645. 